\title{
FUNGICIDE APPLICATION USING A TRAILING BOOM IN SOYBEAN FIELDS
}

\section{PEDRO H. WEIRICH NETO ${ }^{1}$, ALLISON J. FORNARI ${ }^{2}$, FERNANDO C. BAUER ${ }^{3}$, ALTAIR JUSTINO $^{4}$, LUIZ C. GARCIA ${ }^{5}$}

\begin{abstract}
The objective of this study was to determine the effects in the yield of soybean crop utilizing a trailing boom sprayer for chemical control of late season diseases. The experimental design was randomized blocks with 04 treatments, which consisted of applying fungicides with a traditional sprayer, trailing boom, the traditional sprayer plus the trailing boom simultaneously and control (without fungicide aerial application) in 05 repetitions per treatment. The variables evaluated were: final plant population, pods per plant, grains per pod, weight of one thousand grains and yield. It was concluded that the control of foliar diseases with fungicides presented weight of one thousand grains and yield significantly higher than the average of plots without fungicide application. The trailing boom did not significantly affect the yield compared to the technology currently used.
\end{abstract}

KEYWORDS: late season diseases, spray boom, yield components.

\section{APLICAÇÃO DE FUNGICIDAS EM SOJA COM BARRA DE ARRASTO}

RESUMO: O objetivo deste trabalho foi verificar se o controle químico de doenças de final de ciclo com barra de arrasto afeta os componentes de rendimento da cultura da soja em comparação com a tecnologia convencional. O delineamento experimental foi em blocos casualizados, com 04 tratamentos, que consistiram na aplicação de fungicidas com pulverizador terrestre de barra, barra de arrasto, pulverizador de barra mais barra de arrasto, simultaneamente, e testemunha (sem aplicação de fungicidas na parte aérea), em 05 repetições por tratamento. As variáveis avaliadas foram: população final, vagens por planta, grãos por vagem, massa de mil grãos e produtividade. Nas condições experimentais, conclui-se que o controle de doenças foliares com fungicida apresentou massa de mil grãos e produtividade significativamente maior que a média das parcelas sem aplicação de fungicida. A pulverização com barra de arrasto não afetou significativamente os componentes de rendimento em comparação com a tecnologia atualmente utilizada.

PALAVRAS-CHAVE: doenças de final de ciclo, pulverizador de barra, componentes de rendimento.

\section{INTRODUCTION}

Soy has been aggregated to the eating habits of the population, since it is considered a vegetable with high protein concentration (MILANI et al., 2009). Brazil ranks as the second largest producer of soy in the world, right behind the United States (BIAGGIONI \& BOVOLENTA, 2010). In the 2009/2010 harvest, the culture occupied an area of 23.6 million hectares, totaling a production of 68.7 million tons, with an average yield of 2,941kg per hectare (CONAB, 2010).

Among the factors that limit the productivity of soybean in Brazil are about 40 diseases caused by fungi, bacteria, nematodes and viruses. The incidence and severity of these vary

\footnotetext{
${ }^{1}$ Engenheiro Agrícola, Professor Doutor, Universidade Estadual de Ponta Grossa - PR, Departamento de Ciências do Solo e Engenharia Agrícola, Fone: (042) 3220 3090, lama1@uepg.br.

${ }^{2}$ Engenheiro Agrônomo, Fazenda Paiquerê, Piraí do Sul - PR.

3 Prof Adjunto-Depto de Engenharia Rural - Centro de Ciências Rurais - Universidade Federal de Santa Catarina.

${ }^{4}$ Engenheiro Agrônomo, Professor Doutor, Universidade Estadual de Ponta Grossa - PR, Departamento de Ciências do Solo e

Engenharia Agrícola.

${ }^{5}$ Engenheiro Agrônomo, Professor Doutor, Universidade Estadual de Ponta Grossa - PR, Departamento de Ciências do Solo e Engenharia Agrícola.

Recebido pelo Conselho Editorial em: 12-9-2012
}

Aprovado pelo Conselho Editorial em: 29-11-2012 
according to each crop variety, crop rotation, weather conditions and pathogens inoculum source. Without proper control diseases have the potential to cause losses of up to $100 \%$ of production (SANTOS et al., 2007; EMBRAPA, 2008; LUDWIG et al., 2010).

The control of diseases through genetic resistance is the most effective and economical way, but for most of them, there is no resistant cultivars. The removal or retention of the disease, to the level of economic damage, depends on knowledge of the specific requirements of each and integration of various cultural practices, which include: rotation/succession planting, chemical treatment of seeds, varietal resistance, liming and balanced fertilization, appropriate population and best sowing date, weed control and possibly aerial chemical treatment (PESSOA, 1994; BASSETO et al., 2007; NAVARINI et al., 2007; FINOTO et al. 2011).

To infect the soybean plant, the majority of pathogens require much of a liquid medium for germination of their spores. Thus, the lower third of plant presents ideal environmental conditions since it keeps the leaf wetness for a longer period of time. Likewise, it is here that the coverage and penetration of the fungicide are more adversely affected by the leaf weight of tops to form a barrier spraying, favoring the pathogen (ALMEIDA et al. 2,005; CALLA et al. 2,009; REIS et al., 2010; CUNHA et al, 2011). Like most systemic fungicides suitable for chemical control of soybean foliar diseases move in the direction of the base to the apex of the plant, the leaves of the lower third of the plant become the target of spraying (SWOBODA \& PEDERSEN, 2009; ANTUNIASSI et al., 2011; LENZ et al., 2011).

Once the need of using chemical controls with the application of specific products is determined, it must always take into consideration the need of quality process advocated by application technology, defined as the use of all scientific knowledge to provide the correct biologically active product placement on target, in sufficient quantity, cost-effectively and with minimal environmental contamination (MATTHEWS, 2008; ALVARENGA \& CUNHA, 2010; CONSTANTIN et al., 2012, OLIVEIRA et al., 2012).

It is possible to obtain a penetration of the drops in crop canopy changing spray tips, droplet size and spray volume when spraying fungicide on soybeans (MATTHEWS, 2008; DEBORTOLI, et al., 2012). However, CUNHA et al. (2008); NASCIMENTO et al. (2009) and ROMAN et al. (2009) found no significant differences in the chemical control of foliar diseases of soybean spray volumes above 100L ha-1 when evaluating those hypotheses.

The aid of air in the spray bar is also an alternative to increase the penetration of the drops on the plant canopy for the movement of plants and increase soybean productivity (CHRISTOVAM et al., 2010; PRADO et al., 2010; AGUIAR JÚNIOR et al., 2011).

The movement of soybean plants to facilitate penetration of the drops on the plant canopy is also the beginning of a new application technique which consists in a trailing boom with hydraulic circuit and spray nozzles on the crop, an equipment commercially called kit alvo ${ }^{\circledR}$. The aim of this study was to determine whether such equipment promotes the chemical control of foliar diseases of soybean in comparison with the traditional method.

\section{MATERIAL AND METHODS}

The experiment was conducted in the 2010/11 harvest, on a farm located in Pirai do Sul - in the state of Paraná (PR), Brazil, which coordinates are $25^{\circ} 16^{\prime \prime}$ south latitude and $50^{\circ} 16^{\prime \prime}$ west longitude, and its climate is Cfb (IAPAR, 2012 ), with 910m of altitude and has a soil classified as Dystrophic Red-Yellow Latosol (SANTOS et al., 2006). The experiment occurred in a direct seeding system under straw.

A complete randomized block design with 04 treatments was used, which consisted in the chemical control of foliar diseases in soybeans with conventional spray (bar without the aid of air), application with a trailing boom on plants ("target kit” - Alvo Pulverização ${ }^{\circledR}$ (Figure 1)), conventional target kit ${ }^{\circledR}$ simultaneously and control (without aerial application of fungicides) in 05 
replicates per treatment. Each of the 20 plots had an evaluation area of $15 \mathrm{~m}^{2}$. The sample size took into account the stabilization of the average and standard deviation of the variables in accordance with the method proposed by KRANZ (1988).

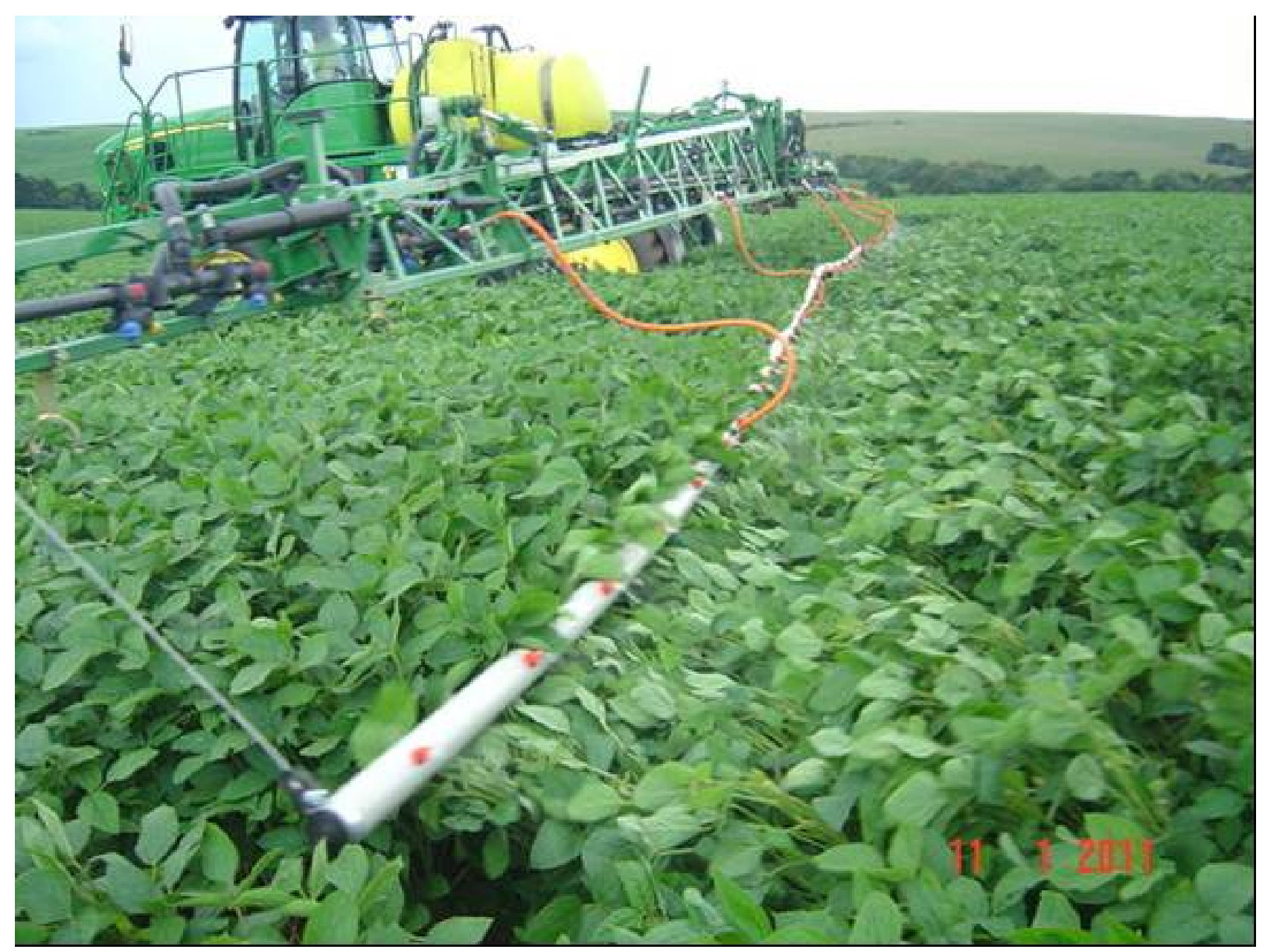

FIGURE 1. Trailing boom (target kit - Alvo Pulverização ${ }^{\circledR}$ ) designed for spraying pesticides in order to improve the penetration of drops in the leaf canopy.

All cultural and phytosanitary practices were performed in accordance with the recommendations of soybean cultivation in the region. The sowing of the soybean cultivar (Glycine $\max \left(\right.$ L.) Merrill) CODETEC 206 occurred on November $8^{\text {th }}$, when 300,000 seeds ha $^{-1}$ were planted. The initial population was assessed 15 days after emergence, resulting in 287,000 plants $\mathrm{ha}^{-1}$.

The soybean cultivar CODETEC 206 is recommended for high regions of Paraná. The relative maturity of the group is 6.8 , has determinate growth, average full flowering at 60 days after emergence, medium to full maturity 130 days after emergence, average plant height around 0.85 meters, lodging resistance, resistant to frogeye leaf spot (Cercospora sojina) and moderately susceptible to powdery mildew (Microsphaera diffuse) (CODETEC, 2009).

Chemical control of the following diseases: anthracnose (Colletotrichum truncatum) leaf blight (Cercospora kikuchii), rust (Phakopsora pachyrhizi), target spot (Corynespora cassiicola), brown spot (Septoria glycines) and powdery mildew (Microsphaera diffuse) is given by the application of $0.5 \mathrm{~L} \mathrm{ha}^{-1}$ of Opera - BASF ${ }^{\circledR}$ fungicide $\left(50 \mathrm{~g} \mathrm{~L}^{-1}\right.$ of Epoxiconazole and $133 \mathrm{~g} \mathrm{~L}^{-1}$ of Pyraclostrobin) at the phenological stage VN/R1, 0.5L ha ${ }^{-1}$ Opera - BASF ${ }^{\circledR}$ at R4 /R5.1 stage and $0.3 \mathrm{~L} \mathrm{ha}{ }^{-1}$ Priori Xtra - Syngenta ${ }^{\circledR}\left(200 \mathrm{~g} \mathrm{~L}^{-1}\right.$ of Azoxystrobin and $80 \mathrm{~g} \mathrm{~L}^{-1}$ Cyproconazole) at stage R5.4. 
The used sprayer was a self-propelled John Deere $4630^{\circledR}$ with Greenstar ${ }^{\circledR}$ AMS system (GS2 1800 monitor, StarFire iTC receptor, SF1, autopilot and automatic controller of the sections), with spray boom with no air aid of $24 \mathrm{~m}$, nozzles spaced $0.5 \mathrm{~m}$ from each other and spray tips on ULD 11002 - Hypro $^{\circledR}$ boom. On target kit ${ }^{\circledR}$, the tip used was DEFLECTOR 0.5 - Magno Jet ${ }^{\circledR}\left(130^{0}\right)$, which accompanied the equipment. The adjustment of the sprayer and target kit ${ }^{\circledR}$ was performed by evaluating the agitation of the spray mixture in the tank with $50 \%$ of its capacity, working pressure in the spray tips with a manometer fit in the nozzle, removal of leakages, checking of spacing of 0.5 meters between nozzles, filters of the hydraulic circuit with mesh defined by the tip and flow variation less than $10 \%$ between the spray tip with a graduated cylinder.

The calibration of the spraying for the conventional treatment (only with a boom) occurred at an average speed of $6.0 \mathrm{~km} \mathrm{~h}^{-1}$, pressure of $120 \mathrm{kPa}$ and thick drop size (HYPRO, 2005). When performing the application with the target kit ${ }^{\circledR}$, the average speed used was of $4.0 \mathrm{~km} \mathrm{~h}^{-1}$, pressure of $200 \mathrm{kPa}$ and thin drop size (MAGNO JET, 2012). For conventional treatment plus the target kit ${ }^{\circledR}$ simultaneously, the average speed used was of $8.2 \mathrm{~km} \mathrm{~h}^{-1}, 100 \mathrm{kPa}$ of pressure and thick drop size for ULD 11002 - Hypro ${ }^{\circledR}$ tip and medium drop size for DEFLECTOR 0.5 - Magno Jet ${ }^{\circledR}$ tip (HYPRO, 2005 and MAGNO JET, 2012). Variations in speed were automatically corrected by the onboard computer, regulated to maintain the flow of the spray in $100 \mathrm{~L} \mathrm{ha}^{-1}$ and not reduce the pressure to below $100 \mathrm{kPa}$.

Sprayings were always performed with relative moisture above $55 \%$, temperature below $30^{\circ} \mathrm{C}$ and wind speed between 3.0 and $10.0 \mathrm{~km} \mathrm{~h}^{-1}$. Weather conditions were monitored by anemo-thermohygrometer Kestrel $3000^{\circledR}$.

The variables evaluated were: final plant population, pods per plant, seeds per pod, weight of one thousand grains and yield. Harvesting, threshing, counting of grains per pod and weight of one thousand grains were performed manually. The determination of the weight of one thousand grains and yield occurred with 1.0\% of impurities and moisture corrected to 14.0\% wb (CLASPAR, 2012). The moisture value was found with the use of a moisture meter (G800 Gehaka ${ }^{\circledR}$ ). The thousand grains weight was determined with a digital scale from 0.1 to $500 \mathrm{~g}$ Diamond ${ }^{\circledR}$.

The Hartley's test was applied for verifying homoscedasticity of variances. Duncan's and F tests were carried out for the measured variables.

\section{RESULTS AND DISCUSSION}

The stabilization of the average and standard deviation of all variables analyzed (KRANZ, 1988) was $10 \mathrm{~m}^{2}$ per plot, below the predetermined area for plots in the experiment. The Hartley’s test indicated the homoscedasticity of variances for all variables studied. Therefore, there was no need for transformation of the averages for applying the F test

There were no significant differences among blocks (Table 1), indicating the homogeneity of the experimental conditions. Yields obtained in the experiment of approximately $4,650 \mathrm{~kg} \mathrm{ha}^{-1}$ were about 35\% above the national average found by CONAB (2010), which raises the possibility of identifying significant differences among the treatments.

PESSOA (1994), BASSETO et al. (2007), NAVARINI et al. (2007), SANTOS et al. (2007), EMBRAPA (2008) LUDWIG et al. (2010) and FINOTO et al. (2011) stated that the importance of disease control in soybeans has been proven to prevent losses in the experimental conditions where the average of the control plots (without aerial fungicide application) was approximately $70 \%$ of the plot yields with chemical. 
TABLE 1. Yield components of soybean (Glycine max L.) with different techniques of applying fungicides, for the 2010/11 harvest in Piraí do Sul (PR).

\begin{tabular}{cccccc}
\hline Treatments & $\begin{array}{c}\text { Final } \\
\text { population } \\
\text { (ha) }\end{array}$ & $\begin{array}{c}\text { Pods per } \\
\text { plant }\end{array}$ & $\begin{array}{c}\text { Grains per } \\
\text { pod }\end{array}$ & $\begin{array}{c}\text { Weight of } \\
\text { one thousand } \\
\text { grains (g) }\end{array}$ & $\begin{array}{c}\text { Productivity } \\
\text { (kg ha }^{-1} \text { ) }\end{array}$ \\
\hline Boom sprayer & $246,222 \mathrm{a}^{1}$ & $46 \mathrm{a}$ & $2,6 \mathrm{a}$ & $162 \mathrm{a}$ & $4,663 \mathrm{a}$ \\
\hline Trailing boom & $247,556 \mathrm{a}$ & $47 \mathrm{a}$ & $2,6 \mathrm{a}$ & $160 \mathrm{a}$ & $4,644 \mathrm{a}$ \\
\hline $\begin{array}{c}\text { Boom sprayer }+ \\
\text { trailing boom }\end{array}$ & $246,667 \mathrm{a}$ & $47 \mathrm{a}$ & $2,5 \mathrm{a}$ & $161 \mathrm{a}$ & $4,623 \mathrm{a}$ \\
\hline Control & $244,444 \mathrm{a}$ & $43 \mathrm{a}$ & $2,5 \mathrm{a}$ & $121 \mathrm{~b}$ & $3,203 \mathrm{~b}$ \\
\hline BLOCKS & $\mathrm{ns}^{2}$ & $\mathrm{~ns}$ & $\mathrm{~ns}$ & $\mathrm{~ns}$ & $\mathrm{~ns}$ \\
\hline CV $(\%)$ & 4.2 & 8.2 & 13.4 & 13.1 & 7.1 \\
\hline
\end{tabular}

1 - Averages followed by the same letter in the column do not differ significantly by the Duncan's Test $(\mathrm{P}>0.05)$. $2-$ Not significant by the F Test $(\mathrm{P}>0.05)$.

Late season leaf diseases did not affect the crop to the point of significantly differ between treatments, with a confidence level greater than 95\% for the final population, pods per plant and grains per pod variables. The income component that differed significantly from the control treatment was the weight of one thousand grains, reflecting the absence of leaf area to generate assimilates to be carried to grain filling.

In the target kit ${ }^{\circledR}$ system, spray hydraulic circuit nozzles are set in a bar and dragged on the crop, assuming greater coverage of the lower leaves of soybean, where the infection of diseases starts, as claimed by ALMEIDA et al. (2005), CALLA et al. (2009), REIS et al. (2010) and CUNHA et al (2011). Since the motion of most fungicides is acropetal (SWOBODA \& PEDERSEN, 2009; ANTUNIASSI et al., 2011 and LENZ et al 2011), spraying the base of plants suggests significantly a more effective control of the diseases when compared to sprayings by tips distant from the apex of soybean plants. However, experimental results indicate that the aggregation of such technology in aerial spraying of fungicide from soybean - isolated or in combination with conventional sprayings - did not differ significantly from the spraying by nozzles on the culture; thus refuting the assumptions that justify the use of such technology application.

\section{CONCLUSIONS}

The late season disease control with fungicide presented weight of one thousand grains and yield significantly higher than the average of plots without fungicide application.

The spraying with trailing boom did not significantly affected yield components compared to the technology used currently.

\section{REFERENCES}

AGUIAR JÚNIOR, H.O.; RAETANO, C.G.; PRADO, E.P.; POGETTO, M.H.A.D.; CHRISTOVAM, R.S.; GIMENES, M.J. Adjuvantes e assistência de ar em pulverizador de barras sobre a deposição da calda e controle de Phakopsora pachyrhizi (Sydow \& Sydow). Summa Phytopathologica, Botucatu, v. 37, n. 3, p. 103-109, 2011

ALMEIDA, A.M.R.; FERREIRA, L.P.; YORINORI, J.T.; SILVA, J.F.V.; HENNING, A.A.; GODOY, C.V.; COSTAMILAN, L.M.; MEYER, M.C. Doenças da Soja. In: KIMATI, H.; AMORIM, L.; BERGAMIN FILHO, A.; CAMARGO, L.E.A.; REZENDE, J.A.M. (Eds.) Manual de fitopatologia: doenças das plantas cultivadas. 4. ed. São Paulo: Agronômica Ceres, 2005. v.2, p. 569-588. 
ALVARENGA, C.B.; CUNHA. J.P.A.R. Aspectos qualitativos da avaliação de pulverizadores hidráulicos de barra na região de Uberlândia, Minas Gerais. Engenharia Agrícola, Jaboticabal, v.30, n.3, p.555-562, 2010.

ANTUNIASSI, U.R.; VELINI, E.D.; OLIVEIRA, R.B.; OLIVEIRA, M.A.P.; FIGUEIREDO, Z.N. Systems of aerial spraying for soybean rust control. Engenharia Agrícola, Jaboticabal, v. 31, n. 4, p. 695-703, 2011.

BASSETO, M.A.; CERESINI, P.C.; VALÉRIO FILHO, W.V. Severidade da mela da soja causada por Rhizoctonia solani AG-1 IA em função de doses de potássio. Summa Phytopathologica, Botucatu, v.33, n.1, p.56-62, 2007.

BIAGGIONI, M.A.M.; BOVOLENTA, F.C. Balanço energético comparativo para rotas de escoamento de soja. Engenharia Agrícola, Jaboticabal, v. 30, n. 4, p. 587-599, 2010 .

CALLA, B.; VUONG, T.; RADWAN, O.; HARTMAN, G.L.; CLOUGH, S.J. Gene expression profiling soybean stem tissue early response to Sclerotinia sclerotiorum and in silico mapping in relation to resistance markers. The Plant Genome, Madison, v.2, n.2, p.149-166, 2009.

CHRISTOVAM, R.S.; RAETANO, C.G.; AGUIAR JUNIOR, H.O.; DAL-POGETTO, M.H.F.; PRADO, E.P.; GIMENES, M.J.; KUNZ, V.L. Assistência de ar em barra de pulverização no controle da ferrugem asiática da soja. Bragantia, Campinas, vol.69, n.1, p. 231-238, 2010.

CLASPAR. Produtos padronizados: soja, 2012. Disponível em: http://www.claspar.pr.gov.br/arquivos/File/pdf/soja_in_11_07_anexo.pdf. Acesso em: 23 jun. 2012. CONAB - Companhia Nacional de Abastecimento. Acompanhamento de safra brasileira. Brasília: Conab, 2010. 44p.

CONSTANTIN, J.; SALES, J.G.C.; MACIEL, C.D.G. Característica da deposição e distribuição da calda de pulverização na cultura da soja em estádio fenológico V6. Engenharia Agrícola, Jaboticabal, v. 32, n.3, p. 283-291, 2012.

COODETEC. Guia de produtos de soja Sul 2010. Cascavel: Coodetec, 2009. 39p.

CUNHA, J. P. A. R.; MOURA, E.S A.C.; SILVA JÚNIOR, J.L.; ZAGO, F.; JULIATTI, F.C. Efeito de pontas de pulverização no controle químico da ferrugem da soja. Engenharia Agrícola, Jaboticabal, v.28, n.2, p. 283-291, 2008.

CUNHA, J.P.A.R.; FARNESE, A.C.; OLIVET, J.J.; VILLALBA, J. Deposição de calda pulverizada na cultura da soja promovida pela aplicação aérea e terrestre. Engenharia Agrícola, Jaboticabal, v.31, n.2, p. 343-351, 2011.

DEBORTOLI, M.P.; TORMEN, N.R.; BALARDIN, R.S.; FAVERA, D.D.; STEFANELLO, M.T.; PINTO, F.F.; UEBEL, J.D. Espectro de gotas de pulverização e controle da ferrugem-asiática-da-soja em cultivares com diferentes arquiteturas de planta. Pesquisa Agropecuária Brasileira, Brasília, v. 47, n. 7, p. 920-927, 2012.

EMBRAPA. Empresa Brasileira de Pesquisa Agropecuária. Tecnologias de produção de soja região central do Brasil - 2009 e 2010. Londrina: Embrapa Soja, 2008. 262p.

FINOTO E.L.F; CARREGA, W.C.; SEDIYAMA, T.; ALBUQUERQUE, J.A.A.; CECON, P.R.; REIS, M.S. Efeito da aplicação de fungicida sobre caracteres agronômicos e severidade das doenças de final de ciclo na cultura da soja. Revista agroambiente, Boa Vista, v.5, n.1, p.44-49, 2011.

HYPRO. Catálogo de pontas de pulverização. Belo Horizonte: COMAM, 2005. 54p.

IAPAR. Instituto Agronômico do Paraná. Classificação climática. Disponível em: <http://www.iapar.br/modules/conteudo/conteudo.php?conteudo=863>. Acesso em: 28 jul. 2012.

KRANZ, J. Measuring plant disease. In: KRANZ, J.; ROTEM, J. (Ed.). Experimental techniques in 
plant disease epidemiology. Heidelberg: Springer, 1988. p.35-50.

LENZ, G.; BALARDIN, R. S.; MINUZZI, S.G.; TORMEN, N.R.; MARQUES, L.N. Espectro de gotas e idade de trifólios na taxa de absorção e efeito residual de fungicidas em soja. Ciência Rural, Santa Maria, v.41, n.10, p.1702-1708, 2011.

LUDWIG, M.P.; DUTRA, L.M.C.; LUCCA FILHO, O.A.; ZABOT, L.; UHRY, D.; LISBOA, J.I. Produtividade de grãos da soja em função do manejo de herbicida e fungicidas. Ciência Rural, Santa Maria, v.40, n.7, p.1516-1522, 2010.

MAGNO JET. Bicos poliacetal para pulverização. Disponível em:

$<$ http://www.magnojet.com.br/magnojet/pt/produtos.php?Catalogo=detalhar_produto\&idProduto=2 74\&categoria=65\&nomeProd=bico_defletor_poliacetal\&OpAcao=MudarFotoProduto\&FotoProdut o=bico_defletor_poliacetal114504894-img2.jpg\&TipoMidiaProduto=Imagem>. Acesso em: 28 jul. 2012.

MATTHEWS, G.A. Developments in application technology. Environmentalist, New York, v. 28, p. 19-24, 2008.

MILANI, A.P.; BIDOIA, V.S.; PERECIN, D. Estudo granulométrico de grãos de soja normal e transgênico. Engenharia Agrícola, Jaboticabal, v. 29, n.4, p. 656-660, 2009.

NASCIMENTO, J.M.; SOUZA, C.M.A.; GAVASSONI, W.L.; BACCHI, L.M.A.; FENGLER, G.W. Controle de ferrugem asiática da soja utilizando-se diferentes pontas de pulverização em Maracaju-MS. Revista Ciências Técnicas Agropecuárias, Habana, v. 18, n. 1, p. 1-6, 2009.

NAVARINI, L.; DALLAGNOL, L.J.;, BALARDIN, R.S.; MOREIRA, M.T.; MENEGHETTI, R.C.; MADALOSSO, M.G. Controle químico da ferrugem asiática (Phakopsora pachyrhizi Sidow) na cultura da soja. Summa Phytopathologica, Botucatu, v. 33, n. 2, p. 182-186, 2007.

OLIVEIRA, G.M.; BALAN, M.G.; FONSECA, I.C.B.; SAAB, O.J.G.A. Sentidos de aplicação e pontas de pulverização no percentual de cobertura em alvos artificiais, para diferentes situações de orientação de alvo e vento. Ciência Rural, Santa Maria, v. 42, n. 4, p. 581-586, 2012.

PESSOA, F. Doenças da soja e seu controle. Piracicaba: POTAFOS, 1994. 11p.

PRADO, E.P.; RAETANO, C.G.; AGUIAR JÚNIOR, H.O.; DAL POGETTO, M.H.F.A.; CHRISTOVAM, R.S.; GIMENESI, M.J.; ARAÚJO, D. PRADO. Velocidade do ar em barra de pulverização na deposição da calda fungicida, severidade da ferrugem asiática e produtividade da soja. Summa Phytopathologica, Botucatu, v.36, n.1, p. 45-50, 2010.

REIS, E.F.; QUEIROZ, D.M.; CUNHA, J.P.A. R.; ALVES, S.M.F. Qualidade da aplicação aérea líquida com uma aeronave agrícola experimental na cultura da soja (Glycine max L.). Engenharia Agrícola, Jaboticabal, v.30, n.5, p.958-966, 2010.

ROMÁN, R.A.A.; CORTEZ, J.W.; FERREIRA, M.C.; OLIVEIRA, J.R.G. Cobertura da cultura da soja pela calda fungicida em função de pontas de pulverização e volumes de aplicação. Scientia Agraria, Curitiba, v.10, n.3, p.223-232, 2009.

SANTOS, H.G.; JACOMINE, P.K.T.; ANJOS, L.H.C.; OLIVEIRA, V.A.; OLIVEIRA, J.B.; COELHO, M.R.; LUMBRERAS, J.F.; CUNHA, T.J.F. Sistema brasileiro de classificação de solos. 2 ed. Rio de Janeiro: EMBRAPA, 2006. 306 p.

SANTOS, J.A.; JULIATTI, F.C.; SANTOS, V.A.; POLIZEL, A.C.; JULIATTI, F.C.; HAMAWAKI O.T. Caracteres epidemiológicos e uso da análise de agrupamento para resistência parcial à ferrugem da soja. Pesquisa Agropecuária Brasileira, Brasília, v.42, n.3, p.443-447, 2007.

SWOBODA, C.; PEDERSEN, P. Effect of Fungicide on Soybean Growth and Yield. Agronomy Journal, Madison, v.101, n.2, p.352-356, 2009. 